\title{
Internal and external restructuring over the cycle: a firm-based analysis of gross flows and productivity growth in Portugal
}

\author{
Carlos Carreira $\cdot$ Paulino Teixeira
}

Published online: 20 December 2007

(C) Springer Science+Business Media, LLC 2007

\begin{abstract}
This paper discusses the role played by internal restructuring vis-à-vis external restructuring in industry productivity growth, arguing that the contribution of these two components is expected to be sensitive to the economic cycle. The study describes gross flows (job and output) over a period of one decade, and analyses the productivity differential among continuing, entering and exiting firms in the Portuguese manufacturing sector. The results of the decomposition of industry productivity growth suggest that the share of external restructuring is stronger in recession, while internal restructuring seems to be predominant in expansion. The strong and positive contribution of the net entry effect, in 1991-1994, was not followed by any between and cross effects of equivalent magnitude in the 1994-1997 sub-period. The within effect is, as expected, stronger when output growth is at its peak, but in no case large enough to turn productivity growth procyclical.
\end{abstract}

Keywords Cleansing - Active and passive learning . Internal restructuring · External restructuring ·

Productivity growth

JEL Classifications $\mathrm{L} 60 \cdot \mathrm{L} 11 \cdot \mathrm{O} 47 \cdot \mathrm{O} 12$

There is a large scope for productivity increases in Portugal, and a set of reforms which could achieve them. (Blanchard, 2007, p. 20)

C. Carreira $(\bowtie) \cdot$ P. Teixeira

GEMF and Faculdade de Economia, Universidade de Coimbra, Av. Dias da Silva, 165, Coimbra 3004-512, Portugal

e-mail: ccarreir@fe.uc.pt

\section{Introduction}

According to a recent report, Portugal lags behind leading OECD countries by $41 \%$ points in terms of GDP per hour worked (OECD 2006). Moreover, the labour productivity growth shows a clear declining trend in the 1990s, especially in the business sector (OECD 2004: Fig. 1.4). This economic performance has attracted the attention of researchers, but, in most studies, attention has been mainly given to aspects related to internal restructuring, that is, to aspects related to productivity changes within existing firms (new technologies, human capital accumulation and organizational changes, for example) rather than to the reallocation across firms or external restructuring (see Simões 1995; Faria et al. 2002, 2005; Teixeira and Fortuna 2004; Monteiro-Barata 2005).

The main purpose of this paper is therefore to examine the contribution of external vis-à-vis internal restructuring to (aggregate) productivity growth. We will also evaluate to what extent these two sources vary over the cycle, by considering that the specific role of internal versus external restructuring on productivity growth depends on the relative importance of cleansing, active learning and passive learning effects. By the cleansing effect-an effect identified by Schumpeter $(1934,1939)$ and other eminent preKeynesian 'liquidationists' (see DeLong 1990; Aghion and Saint-Paul 1998) — we mean the process in which less efficient firms (or technologies) are replaced by more efficient units, while the passive learning effect, or selection across firms, comes from firms' ability to learn their own, pre-determined (but unknown) productivity, and according to which firms expand when they realize they are efficient and shrink (or even exit) when they learn they are not (e.g. Jovanovich 1982). The active learning effect in turn is taken as an outcome of firms' investment in research 
and development designed to improve their competitive capabilities (e.g. Ericson and Pakes 1995).

The relative importance of internal versus external restructuring depends of course on how the cleansing, passive learning, and active learning effects perform in the different phases of the cycle. The Schumpeterian literature, for example, has suggested that cleansing is countercyclical, based on the argument that resource reallocation seems to be more intense in recessions (see Caballero and Hammour 1994, 1996; Mortensen and Pissaridies 1994; the evidence on job flows for the United States manufacturing sector can be found in Davis and Haltiwanger 1992; Davis et al. 1996; Baldwin et al. 1998, inter al.). But if relatively inefficient units disappear in recessions, then, other things constant, productivity growth should be countercyclical, a proposition often at odds with the data (see Aizcorbe 1992; Caballero and Hammour 2005; and Hart and Malley 1999). Recent theoretical literature has indeed suggested that the cleansing effect may be dominated or reversed by other effects arising, for example, from on-the-job search, credit market frictions or (insufficient) passive learning (e.g. Barlevy 2002, 2003; and Ouyang 2005)—while the incentive to invest in R\&D in downturns may be higher (the cost of growth-enhancing activities in terms of forgone output or sales is lower in recessions), financial constraints are higher too (Barlevy 2003, 2004), and one cannot exclude that excessive exit in downturns may impede potentially superior units to flourish (the "scarring" effect of recessions, Ouyang 2005). Since the active and passive learning effects are expected to be procyclical, the combination of the three effects-cleansing, passive and active learning-is then expected to imply that, as a general rule, productivity growth should be procyclical.

By offering a detailed, firm-level, productivity analysis of the Portuguese manufacturing sector in a period of one decade, we aim to shed further light over these controversial issues. To this end, three main contributions are offered in this paper. Firstly, it adds new evidence on job and output gross flows using an original panel of Portuguese manufacturing firms. Secondly, it complements-for Portugal - the OECD survey (2001a) on the determinants of productivity growth by offering two alternative measures-total factor productivity (TFP) and labour productivity (LP). Finally, and more importantly, this paper decomposes the productivity growth into four components-within, between, cross, and net entry, as suggested by Foster et al. (2001) and Griliches and Regev (1995) and discusses the cyclical pattern of internal versus external restructuring by drawing on the assumption that internal restructuring is captured by the within effect, while external restructuring is explained by across firm effects (i.e. between, cross, and net entry). We further assume in this context that the within component of productivity growth reflects mainly firms' active learning, while the between and cross effects mirror market selection or passive learning (across continuing firms), as suggested by Audretsch and Klepper (2000: p. xvi). The net entry effect, in turn, captures mostly the cleansing effect. The main purpose of this mapping is, above all, to offer a workable device that enables us to organize in a simple way the discussion of our findings. In reality, these effects are not so neat. The active learning effect, for example, by increasing the productivity level, may cause an increase in firm's market share, an effect that leads to an increase in the between and cross components. On the other hand, the net entry effect, which in our analysis is made equivalent to the cleansing effect, cannot unequivocally distinguish cleansing from passive learning when the latter induces either exit of less efficient units or growth of newly created efficient firms. The same can be said about the connection between cleansing and active learning (see Geroski 1995: p. 434). ${ }^{1}$

Our empirical enquiry is based on a newly-assembled panel of manufacturing firms covering the period 19912000 (annual data). The dataset is representative of the manufacturing activity of the central region of Portugal (Região Centro, NUT II) and it has the unique feature of unambiguously identifying new firms as well as closures (shutdowns). Since it contains all input and output information required to determine the TFP and labour productivity, our dataset is particularly fitted to carry out productivity analysis.

According to our decomposition exercise, we found that the strong and positive contribution of the cleansing effect in 1991-1994 was not followed by a reallocation across continuing firms of equivalent magnitude in 1994-1997. Our conclusion is then that in Portugal the competitive pressure towards inefficient firms to shrink is insufficient in expansions. The within effect is, as expected, stronger when output growth is at its peak, but in no case large enough to turn productivity growth procyclical.

The paper is organized as follows. Section 2 presents the data and two alternative productivity growth decomposition methods. Section 3 evaluates the importance of production and employment reallocation flows over the cycle. Section 4 analyses the productivity differential among continuing, entering and exiting firms. Section 5 presents the results of the productivity decomposition exercise and Sect. 6 offers some concluding remarks.

\footnotetext{
${ }^{1}$ Foster et al. (2001: p. 338) show indeed that, when the productivity decomposition covers a sufficiently long period, both the selection (passive learning) and (active) learning effects are present in the contribution of net entry to productivity growth.
} 


\section{Data and methodology}

\subsection{The dataset}

The raw data is drawn from the Inquérito às Empresas Harmonizado (IEH), an annual business survey run by the Portuguese Statistical Office (INE). It contains, in particular, detailed information on input and output, required to determine total factor productivity at firm level. The sample of manufacturing firms comprises some 1,900 units, observed over a 10-year period (1991-2000, unbalanced panel). In the sample, firms with more than 100 employees were chosen with certainty, while those with 20-99 employees were drawn randomly. As will be seen in Sect. 3, our results are weighted to ensure they are representative of the population of the central region of Portugal. The sample is considered representative with respect to sectoral disaggregation (at 3-digit level), both in terms of employment size and output (sales). ${ }^{2}$

The longitudinal dimension of the panel was constructed using firm's identification number in the IEH dataset. Additional information with respect to the year of birth/ death was drawn from Ficheiro de Unidades Estatiśticas (FUE), also run by INE. By combining these two datasets (IEH and FUE), it was then possible to determine, with no margin of error, the status of any given unit in any given period: continuing, entering (newly created) or exiting (closure). ${ }^{3}$

\subsection{Measurement of productivity}

The index of firm-level TFP calculated here is similar to that used by Baily et al. (1992), with firm-level productivity ( $\ln \mathrm{TFP}$ ) for firm $i$ in year $t$ given by: ${ }^{4}$

$\ln T F P_{i t}=\ln Q_{i t}-\alpha_{K} \ln K_{i t}-\alpha_{L} \ln L_{i t}-\alpha_{M} \ln M_{i t}$,

where $Q_{i t}$ is the real gross output of the $i$ th firm in year $t$, and $K_{i t}, L_{i t}$ and $M_{i t}$ are capital, labour and intermediate inputs, respectively; $\alpha_{\mathrm{j}}$ denotes factor elasticities, $j=K, L, M$.

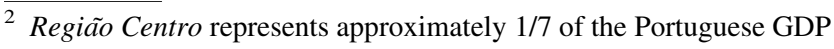
and $1 / 6$ of total employment. Either in terms of employment or output, the shares of each one of the 17 sub-sectors in the manufacturing aggregate at national and Região Centro level are virtually the same, with, for example, the observed differences in 2000 never exceeding six percentage points.

${ }^{3}$ We use firm's reference number and the information on the FUE file to identify entry and exit, so that if, in a given year, there is a new reference number in the panel and the corresponding firm is 1 or 2 years old (in the FUE file), then the firm is taken as a new firm. An exit from the sample is taken as a true exit if and only if the corresponding firm has been coded as non-active in the FUE file. Any change in sector of activity (at 3-digit level) is taken as an entry/exit.

${ }^{4}$ This approach was also followed by Haltiwanger (1997), Foster et al. (2001) and Disney et al. (2003).
}

The index of firm-level labour productivity $(\ln \mathrm{LP})$ for firm $i$ in year $t$ is calculated as the log of the value added per unit of labour, that is:

$\ln L P_{i t}=\ln V A_{i t}-\ln L_{i t}$,

where $V A_{i t}$ is the value added for the $i$ th firm in year $t$.

The gross output is given by the sum of total revenues from sales, services rendered, self-consumption of own production and the change in inventory of final goods. It is deflated by the producer price index at the 3-digit level. The labour input is a 12-month employment average. The labour costs embrace all employment costs, including those incurred through social security payments, and were deflated by the manufacturing industry labour price index. The intermediate input includes the cost of materials, services purchased, and other operating costs; it is deflated by the GDP deflator. Capital stock is measured as the book value of total net assets. Capital services are defined as the sum of the depreciation and the interest on the net asset. The real interest rate is computed as the difference between annual average of the long-term enterprise interest rates and the annual consumer price index. Finally, factor elasticities $\alpha_{K}, \alpha_{L}$ and $\alpha_{M}$ are given by the corresponding industry average cost shares.

\subsection{Decomposition methods of aggregate productivity growth}

The industry productivity level, $P_{t}$, in year $t$ can be defined as the weighted average of firms' productivity levels, that is, $P_{t}=\sum_{i} \theta_{i t} p_{i t}$, where $\theta_{i t}$ is the output (or employment) share of the $i$ th firm in year $t$ and $p_{i t}$ is the corresponding productivity level (TFP or LP). Clearly, industry productivity growth can occur through changes in $p_{i t}$ or $\theta_{i t}$, that is, either through changes in the productivity level across micro units or through changes in their market shares, which in turn will reflect entry, exit and expansion/contraction of continuing firms.

In our study we have followed two routes to decompose industry productivity growth. (Alternative methods can be found in Foster et al. 2001; Baldwin and Gu 2002; Balk and Hoogenboom-Spijker 2003). The first was proposed by Foster et al. (2001) and is given by (FHK henceforth):

$$
\begin{aligned}
\Delta P_{t}= & \sum_{i \in C} \theta_{i(t-\tau)} \Delta p_{i t}+\sum_{i \in C} \Delta \theta_{i t}\left(p_{i(t-\tau)}-P_{t-\tau}\right)+\sum_{i \in C} \Delta \theta_{i t} \Delta p_{i t} \\
& +\sum_{i \in E} \theta_{i t}\left(p_{i t}-P_{t-\tau}\right)-\sum_{i \in X} \theta_{i(t-\tau)}\left(p_{i(t-\tau)}-P_{t-\tau}\right),
\end{aligned}
$$

where $C, E$, and $X$ denote the sets of continuing, entering, and exiting firms between $t-\tau$ (the base year) and $t$, respectively. $P_{t-\tau}$ is the aggregate productivity in $t-\tau$. 
The first term in Eq. 3, called the "within effect" or internal restructuring, represents the productivity growth within continuing firms (weighted by initial shares in the industry). The second term-the "between effect"reflects the aggregate productivity improvement coming from high-productivity continuing firms' expanding shares (or from low-productivity continuing firms' contracting shares). The third term-the "cross effect"-represents a covariance term. In this case, any gains in aggregate productivity will come from increasing (decreasing) shares of continuing firms with growing (falling) productivities. The last two terms on the right-hand-side of Eq. 3 capture the contribution of entering and exiting firms, the "entry" and "exit" effects, respectively. The entry effect is positive if an entering firm's productivity level is larger than the initial industry productivity level; the exit effect is positive if an exiting firm's productivity level is smaller than the initial industry productivity level. (The weights are given by final- and initial-period firm's share in the industry, respectively.)

An alternative route (GR henceforth), based on Griliches and Regev (1995) has also been suggested by Foster et al. (2001):

$$
\begin{aligned}
\Delta P_{t}= & \sum_{i \in C} \bar{\theta}_{i} \Delta p_{i t}+\sum_{i \in C} \Delta \theta_{i t}\left(\bar{p}_{i}-\bar{P}\right)+\sum_{i \in E} \theta_{i t}\left(p_{i t}-\bar{P}\right) \\
& -\sum_{i \in X} \theta_{i(t-\tau)}\left(p_{i(t-\tau)}-\bar{P}\right),
\end{aligned}
$$

where $\overline{\theta_{\mathrm{i}}}, \overline{p_{i}}$, and $\bar{P}$ are the average of each variable over the base and end year. The first term is the within effect, the second is the between effect and the third and fourth terms are the entry and exit effects. (There is no cross-effect term.) The main advantage of the GR decomposition is that by averaging over the base- and end-year it reduces the impact of any measurement error.

\section{Job and output flows}

Our analysis divides the sample period into three subperiods of equal length: 1991-1994, 1994-1997 and 19972000. As Fig. 1 shows, the manufacturing output growth rate is highly decreasing (and even negative) in the first sub-period, while in 1994-1997 it is positive and increasing (except in 1996); ${ }^{5}$ in the third period (1997-2000), albeit positive, it is clearly decreasing. The growth rate for

\footnotetext{
5 The fall in the manufacturing growth rate in 1996 is mostly a statistical artefact connected to changes in the official sector classification, that is, to changes in sectoral classification from CAE-rev.1 to CAE-rev.2. The series associated with CAE-rev2 shows indeed a growth rate of $5.6 \%$ in 1996 , followed by a growth rate of $3.4 \%$ in 1997 . Since the CAE-rev2 series starts only in 1995, only the CAE-rev1 series is kept in Fig. 1.
}

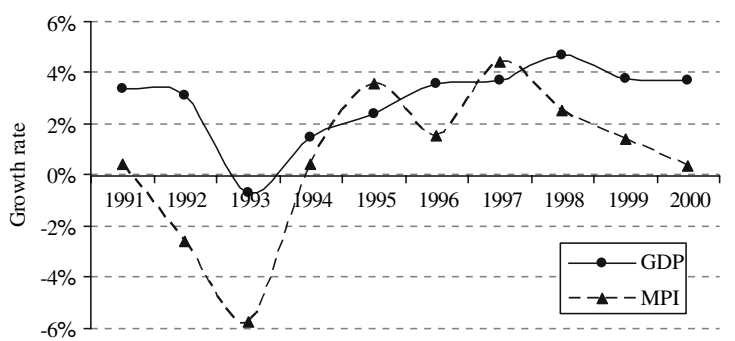

Fig. 1 Growth Rates of GDP and Manufacturing Production Index, 1991-2000 Source: Banco de Portugal and Instituto Nacional de Estatística (INE). Notes: GDP denotes the annual growth rate of real GDP, while MPI denotes the annual growth rate in the Manufacturing Production Index

the whole economy, given by the GDP series, does not replicate entirely the manufacturing profile, but it is clear that there is an overall slowdown in 1991-1994, which is followed by an economic recovery that in the last subperiod loses momentum.

Table 1 shows output and job reallocation rates in manufacturing. It also gives the corresponding fraction due to entry and exit of firms. We note that, as in Davis et al. (1996), production/job creation in a given year $t$ equals production/employment gains summed over all expanding and newly created firms between $t-1$ and $t$. Likewise, production/job destruction in year $t$ equals production/ employment losses summed over all contracting and closing firms between $t-1$ and $t$. The rates were calculated using the average of beginning- and ending-period values of the respective variable as a denominator. Small and large firms were weighted to ensure results were representative of the population at sector level. The aggregate results for the entire manufacturing sector were also sector weighted.

In terms of output, the creation rate varies between $10.6 \%$ (in 1993) and 19.8\% (in 1996), while the destruction rate ranges from $5.3 \%$ (in 1999) to $14.2 \%$ (in 1993). The average output creation (destruction) rate is $13.4 \%$ (7.1\%) over the sample period (last row, columns 1 and 3 of the table).

In terms of job creation (destruction), the average rate is $8.4 \%(8.0 \%)$. The maximum rate of job creation is $14.7 \%$ (in 1996) and the minimum is $6.0 \%$ (in 1993). The destruction rate ranges from $12.5 \%$ (in 1993) to $5.2 \%$ (in 1998). Over the entire sample period, net job creation is slightly positive at $0.4 \%$, while net production creation is equal to $6.3 \%$.

These job flows broadly confirm the pattern observed in other European countries, as reported by Klette and Mathiassen (1996), Broersma and Gautier (1997) and Vainiomaki and Laaksonen (1999), for example. The job flows in Table 1 are also similar to those found by Addison and Teixeira (2004) for a sample of continuing Portuguese manufacturing firms, in the period 1990-1997. Given that 
Table 1 Output and job reallocation rates in Portuguese manufacturing

\begin{tabular}{|c|c|c|c|c|c|c|c|c|}
\hline & \multicolumn{4}{|l|}{ Output } & \multicolumn{4}{|c|}{ Employment } \\
\hline & $\begin{array}{l}\text { Creation } \\
\text { rate }(\%)\end{array}$ & $\begin{array}{l}\text { Share due } \\
\text { to entrants }\end{array}$ & $\begin{array}{l}\text { Destruction } \\
\text { rate }(\%)\end{array}$ & $\begin{array}{l}\text { Share due } \\
\text { to exits }\end{array}$ & $\begin{array}{l}\text { Creation } \\
\text { rate }(\%)\end{array}$ & $\begin{array}{l}\text { Share due } \\
\text { to entrants }\end{array}$ & $\begin{array}{l}\text { Destruction } \\
\text { rate }(\%)\end{array}$ & $\begin{array}{l}\text { Share due } \\
\text { to exits }\end{array}$ \\
\hline 1992 & 12.4 & 0.208 & 8.4 & 0.180 & 8.2 & 0.264 & 9.5 & 0.100 \\
\hline 1993 & 10.6 & 0.495 & 14.2 & 0.033 & 6.0 & 0.628 & 12.5 & 0.095 \\
\hline 1994 & 15.9 & 0.353 & 5.6 & 0.207 & 9.1 & 0.676 & 9.7 & 0.144 \\
\hline 1995 & 12.2 & 0.070 & 5.9 & 0.009 & 6.5 & 0.235 & 6.6 & 0.018 \\
\hline 1996 & 19.8 & 0.352 & 6.1 & 0.089 & 14.7 & 0.590 & 7.9 & 0.181 \\
\hline 1997 & 13.9 & 0.047 & 6.3 & 0.468 & 6.2 & 0.097 & 7.1 & 0.332 \\
\hline 1998 & 11.7 & 0.197 & 5.6 & 0.111 & 8.4 & 0.299 & 5.2 & 0.172 \\
\hline 1999 & 13.5 & 0.204 & 5.3 & 0.209 & 9.0 & 0.388 & 7.1 & 0.291 \\
\hline 2000 & 10.7 & 0.281 & 6.9 & 0.392 & 7.9 & 0.343 & 6.9 & 0.386 \\
\hline Average & 13.4 & 0.245 & 7.1 & 0.189 & 8.4 & 0.391 & 8.0 & 0.191 \\
\hline
\end{tabular}

Notes: Percentage of the average output (employment) of periods $t$ and $t-1$. Small and large firms weighted at sector-level; aggregation weighted over 17 two-digit industries

our dataset excludes firms with less than 20 employees, our figures are lower than those reported by Blanchard and Portugal (2001).

Entry and exit of course play an important part in gross flows. On average, entry contributes to (approximately) one fourth of output creation flows, while exit contributes to one fifth of output destruction (last row, columns 2 and 4, respectively). The share of entry is even bigger in the case of job creation at roughly $40 \%$, while the share of exit is roughly the same at $19 \%$.

Figure 2 panels a and b, plot output and job creation and destruction rates, respectively. Clearly, destruction flows are more sizeable in the first sub-period, while creation tends to be more intense in the second sub-period, especially in terms of output.

Table 2 contains the correlation between different pairs of variables: creation, destruction, net creation and (gross) reallocation flows. ${ }^{6}$ As expected, there is a strong and positive correlation between (gross) creation and net creation and a strong and negative correlation between (gross) destruction and net creation, in terms of both output and employment. Creation flows are thus pro-cyclical, while destruction flows are countercyclical, as reported in many other European countries (e.g. Klette and Mathiassen 1996; Albaek and Sorensen 1998; Garibaldi 1998; Vainiomaki and Laaksonen 1999). Reallocation flows (i.e. creation plus destruction) also tend to exhibit a slightly pro-cyclical pattern as in other European countries, especially in terms of employment (Garibaldi 1998).

\footnotetext{
${ }^{6}$ As usual, net creation is given by the difference between creation and destruction, while the reallocation rate is given by the sum of creation and destruction.
}
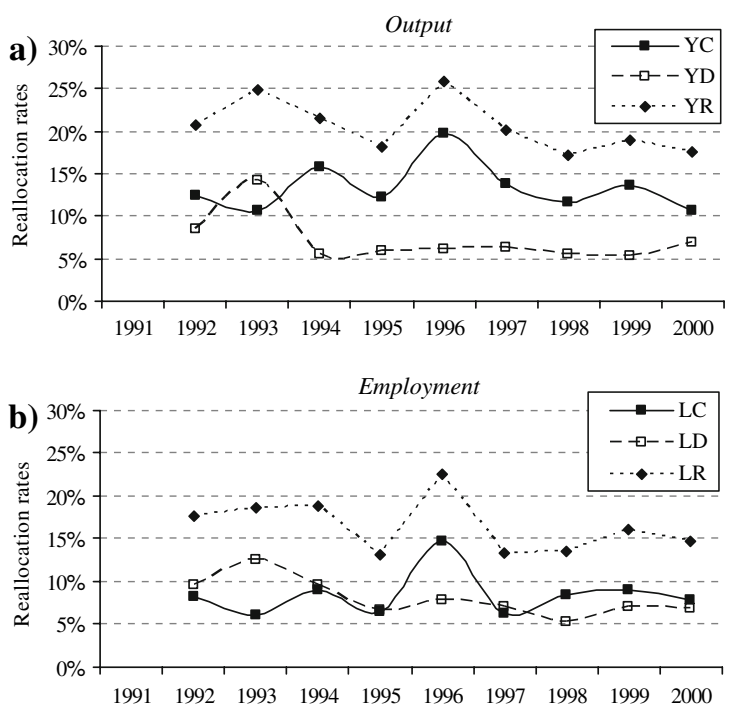

Fig. 2 Creation and destruction rates (output and employment) Notes: YC, YD and YR denote creation, destruction and reallocation rates of output and LC, LD and LR those rates of employment. Small and large firms weighted at sector-level; aggregation weighted over 17 two-digit industries

\section{Productivity gap among continuing, entering and exiting firms}

Given the size of the observed creation and destruction flows, a key issue is of course whether less productive firms have been replaced by more productive units. As panels a and $b$ of Fig. 3 show, the productivity of continuing firms is always the highest among the three groups (continuing, entering, and exiting firms). At the same time, the productivity level of entrants is higher than that of exiting firms except in two occasions: in 1997 and 1999 in the TFP case, and in 1991 and 1995 in the LP case. Finally, the 
Table 2 Correlation between creation, destruction, net creation and reallocation flows

\begin{tabular}{llllllrr}
\hline & Output & & & \multicolumn{2}{l}{ Employment } & \\
\cline { 2 - 3 } & Destruction & Net creation & Reallocation & & Destruction & Net creation & Reallocation \\
\hline Creation & $-0.424(0.26)$ & $0.850(0.00)$ & $0.559(0.12)$ & & $-0.128(0.74)$ & $0.800(0.01)$ & $0.732(0.02)$ \\
Destruction & & $-0.838(0.00)$ & $0.514(0.16)$ & & $-0.698(0.04)$ & $0.582(0.10)$ \\
Net creation & & & $0.038(0.92)$ & & $0.177(0.65)$ \\
\hline
\end{tabular}

Notes: Net creation is given by the difference between creation and destruction. In the case of job flows, annual net creation is equivalent to net employment growth. Reallocation is given by the sum of creation and destruction. Marginal significance in parentheses

productivity level required for entry seems to be higher in recession than in expansion, especially in terms of labour productivity. The productivity gap between new firms and exiting firms is also higher in the 1991-1994 sub-period (on average, $14 \%$ points in the TFP case and $31 \%$ points in the LP case).

As Geroski (1995), Caves (1998), and Ahn (2001) have shown, productivity is strongly increasing (decreasing) in the post-entry (pre-exit) period. In Table 3 and for each sub-period we therefore compare the productivity of entering (exiting) units in the ending (beginning) year with the productivity of continuing firms in the beginning year of the corresponding sub-period. Clearly, the productivity of new firms is higher than that of continuing firms when the productivity of the latter is measured in the beginning year (an exception to this result is the third sub-period). Following an identical computation, the productivity of entering firms is also much higher than
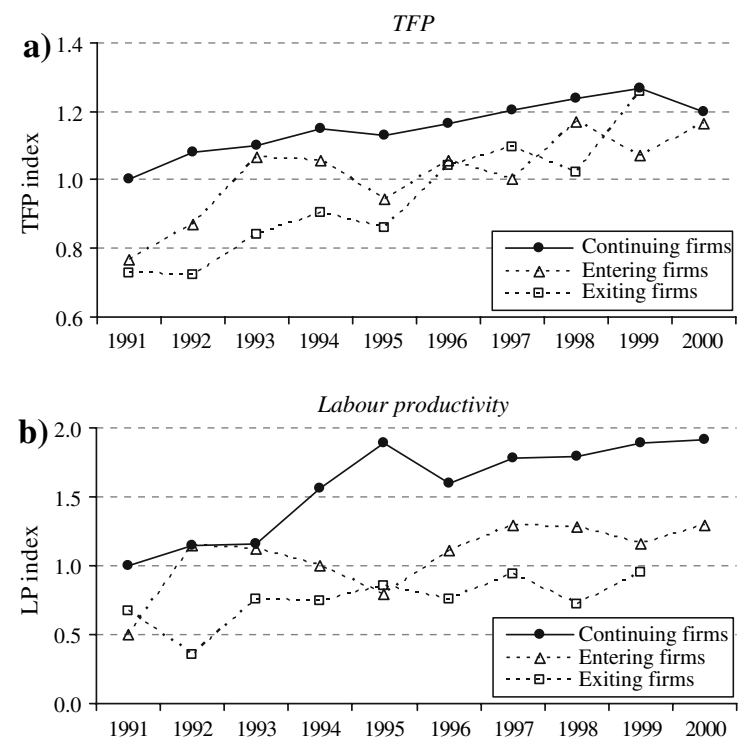

Fig. 3 TFP and labour productivity Notes: Average weighted by firm's output in panel (a) and by firm's employment in panel (b). The two indicators are set to 100 for continuing firms in 1991. Small and large firms weighted at sector-level; aggregation weighted over 17 two-digit industries that of exiting firms. In the 1991-1994 sub-period, for example, the TFP of entrants is $9 \%$ points higher than that of continuing firms (measured in the beginning year), while the productivity of exiting firms is $25.1 \%$ points below (rows two and three of Table 3 ). The total productivity gap between entering and exiting firms is therefore no less than $34 \%$ points. This gap is even larger in the case of LP, at $37.3 \%$ points. In subsequent periods the gap is clearly smaller which means that productivity gains from net entry can be especially strong in economic slowdowns.

\section{Quantifying the contribution of internal and external restructuring to industry productivity growth}

In this section we decompose productivity growth into its main components (within, between, cross, and net entry) to obtain the specific contribution of each source in each of the selected sub-periods.

As Fig. 4 shows, both the TFP and LP growth rates present a clear declining trend over the period 1991-2000. Indeed, in the 1991-1994 period, the TFP growth rate was $3.0 \%$ per annum, while during the second sub-period (i.e. 1994-1997) it was $2.5 \%$, reaching a negative annual growth rate at $-0.1 \%$ in the $1997-2000$ period. The corresponding average growth rate in the LP case was 4.0, 2.7, and $1.5 \%$. These figures broadly confirm those reported by the OECD (2001b, p. 32), which indicate, for the Portuguese manufacturing sector, a $3 \%$ point reduction in labour productivity growth between 1996 and 1999.

The results of the productivity growth decomposition exercise are given in Table 4 and Fig. 5. Clearly, the two selected decomposition methods (FHK and GR) indicate that the within effect (or internal restructuring) is the dominant source of aggregate productivity growth, with a contribution ranging from 40\% (in the 1991-1994 periodthe FHK case) to $87 \%$ (in 1994-1997-the GR case). The dominance of the within effect is somewhat smaller in the labour productivity case, with the corresponding share 
Table 3 Productivity differentials relative to continuing firms

\begin{tabular}{|c|c|c|c|c|}
\hline \multirow[b]{3}{*}{ Period: 1991-1994 } & \multicolumn{4}{|c|}{ In the beginning/ending year } \\
\hline & \multicolumn{2}{|l|}{ TFP } & \multicolumn{2}{|l|}{ LP } \\
\hline & Beginning year: 1991 & Ending year: 1994 & Beginning year: 1991 & Ending year: 1994 \\
\hline Continuing firms & 100 & 113.3 & 100 & 121.8 \\
\hline Entering firms & - & 108.5 & - & 110.6 \\
\hline Exiting firms & 74.9 & - & 73.3 & - \\
\hline Period: 1994-1997 & Beginning year: 1994 & Ending year: 1997 & Beginning year: 1994 & Ending year: 1997 \\
\hline Continuing firms & 100 & 110.3 & 100 & 119.4 \\
\hline Entering firms & - & 107.0 & - & 136.7 \\
\hline Exiting firms & 88.4 & - & 77.9 & - \\
\hline Period: 1997-2000 & Beginning year: 1997 & Ending year: 2000 & Beginning year: 1997 & Ending year: 2000 \\
\hline Continuing firms & 100 & 101.6 & 100 & 109.6 \\
\hline Entering firms & - & 90.9 & - & 95.0 \\
\hline Exiting firms & 90.6 & - & 82.8 & - \\
\hline
\end{tabular}

Notes: Average weighted by firm's output (TFP) and employment (LP); small and large firms weighted at sector-level; aggregation weighted over 17 two-digit industries. For each sub-period, the productivity of entering (exiting) is expressed in relation to the productivity of continuing firms measured in the beginning year. The group of entering (exiting) firms comprises all firms that enter (exit) in the corresponding sub-period. Simultaneous entry and exit within any sub-period is excluded

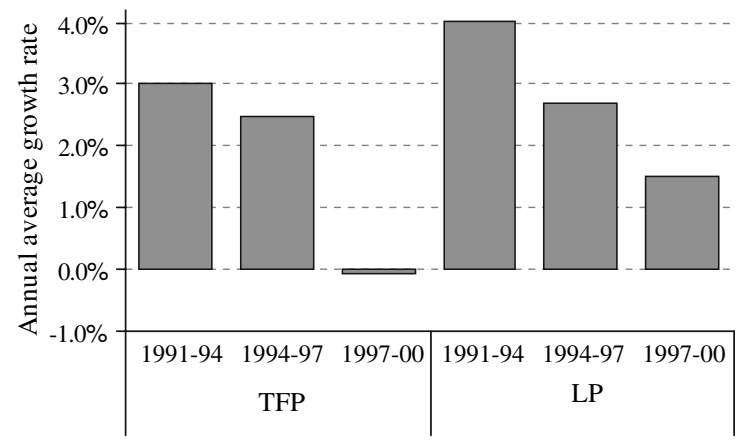

Fig. 4 Annual average growth rate of TFP and labour productivity Note: See Fig. 3

ranging between $31 \%$ and $65 \%$ (in $1997-2000$ and $1994-$ 1997, respectively). ${ }^{7}$

The share of the within effect increases visibly in the second sub-period, explaining more than $3 / 4$ of the observed productivity (TFP) growth in the FHK decomposition. In the GR decomposition the share of the within effect is even bigger at $87 \%$ of the observed productivity growth. The labour productivity measure implies a slightly smaller increase from 1991-1994 to 1994-1997 in either method,

7 We note that the GR method leads to an overvaluation of the within effect, as it equals the within effect plus one half the cross effect corresponding to the FHK method, that is:

$$
\begin{aligned}
\sum_{i \in C} \bar{\theta}_{i} \Delta p_{i t} & =\sum_{i \in C}(1 / 2)\left(\theta_{i t}+\theta_{i(t-\tau)}\right) \Delta p_{i t} \\
& =\sum_{i \in C}(1 / 2)\left(\theta_{i(t-\tau)}+\Delta \theta_{i t}+\theta_{i(t-\tau)}\right) \Delta p_{i t} \\
& =\sum_{i \in C} \theta_{i(t-\tau)} \Delta p_{i t}+(1 / 2) \sum_{i \in C} \Delta \theta_{i t} \Delta p_{i t} .
\end{aligned}
$$

FHK or GR. The share of the within effect in 1997-2000 falls to approximately $1 / 3$ of the observed labour productivity growth. This pro-cyclical contribution of the within effect has also been found by Baily et al. (1992) and Foster et al. (2001). ${ }^{8}$

For its part, external restructuring accounts for approximately $60 \%$ of the TFP growth observed in 1991-1994, falling substantially in 1994-1997 to $22 \%$ in the FHK case (40 and $13 \%$ in the GR case, respectively). In terms of labour productivity, external restructuring explains more than $2 / 3$ in 1991-1994 and 1997-2000 and approximately $40 \%$ in 1994-1997. As far as the specific components of external restructuring are concerned, the between and cross effects represent a total of $41 \%$ of the observed TFP growth in the first sub-period, falling to $11 \%$ in the 1994-1997 period. The share of the between and cross effects in labour productivity growth is also smaller in the second sub-period at only 23\%. (The shares in 1991-1994 and 1997-2000 were 38 and $41 \%$, respectively.) Finally, external restructuring due to entry and exit is equal to $19 \%$ of the observed TFP growth in the first period, to fall to $11 \%$ in 1994-1997. In terms of LP, the shares in the three sub-periods are equal to 30,17 , and $28 \%$, respectively, mostly due to the exit effect.

To summarize, the first main finding is therefore that the net entry effect is stronger when economic growth is smaller, a result that we interpret as evidence in favour of

\footnotetext{
${ }^{8}$ Given that the productivity growth in the third sub-period is very small, we have refrained from presenting the corresponding share figures.
} 
Table 4 Productivity decomposition

\begin{tabular}{|c|c|c|c|c|c|c|}
\hline & Within & Between & Cross & Net entry & Entry & Exit \\
\hline \multicolumn{7}{|c|}{$\Delta \ln \mathrm{TFP}$} \\
\hline \multicolumn{7}{|c|}{ 1991-1994 (Average productivity growth $3.00 \%$ per annum) } \\
\hline FHK & $0.0356(40.2 \%)$ & $0.0014(1.6 \%)$ & $0.0352(39.7 \%)$ & $0.0164(18.5 \%)$ & $0.0136(15.3 \%)$ & $0.0028(3.1 \%)$ \\
\hline GR & $0.0532(60.2 \%)$ & $0.0227(25.7 \%)$ & & $0.0125(14.1 \%)$ & $0.0076(8.6 \%)$ & $0.0049(5.5 \%)$ \\
\hline \multicolumn{7}{|c|}{ 1994-1997 (Average productivity growth $2.49 \%$ per annum) } \\
\hline FHK & $0.0577(78.3 \%)$ & $-0.0045(-6.1 \%)$ & $0.0124(16.8 \%)$ & $0.0081(11.0 \%)$ & $0.0062(8.4 \%)$ & $0.0020(2.7 \%)$ \\
\hline GR & $0.0639(87.0 \%)$ & $0.0031(4.3 \%)$ & & $0.0065(8.8 \%)$ & $0.0031(4.2 \%)$ & $0.0034(4.6 \%)$ \\
\hline \multicolumn{7}{|c|}{ 1997-2000 (Average productivity growth $-0.08 \%$ per annum) } \\
\hline FHK & -0.0091 & 0.0029 & 0.0075 & -0.0036 & -0.0038 & 0.0003 \\
\hline GR & -0.0054 & 0.0062 & & -0.0029 & -0.0035 & 0.0006 \\
\hline \multicolumn{7}{|c|}{$\Delta \ln \mathrm{LP}$} \\
\hline \multicolumn{7}{|c|}{ 1991-1994 (Average productivity growth $4.02 \%$ per annum) } \\
\hline FHK & $0.0384(32.4 \%)$ & $0.0208(17.6 \%)$ & $0.0239(20.2)$ & $0.0353(29.8 \%)$ & $0.0084(7.1 \%)$ & $0.0269(22.7 \%)$ \\
\hline GR & $0.0503(42.4 \%)$ & $0.0379(32.0 \%)$ & & $0.0305(25.7 \%)$ & $-0.0003(-0.3 \%)$ & $0.0308(25.9 \%)$ \\
\hline \multicolumn{7}{|c|}{ 1994-1997 (Average productivity growth $2.69 \%$ per annum) } \\
\hline FHK & $0.0478(60.0 \%)$ & $0.0114(14.3 \%)$ & $0.0067(8.4 \%)$ & $0.0138(17.3 \%)$ & $0.0029(3.6 \%)$ & $0.0109(13.7 \%)$ \\
\hline GR & $0.0512(64.5 \%)$ & $0.0160(20.2 \%)$ & & $0.0122(15.3 \%)$ & $-0.0010(-1.3 \%)$ & $0.0132(16.6 \%)$ \\
\hline \multicolumn{7}{|c|}{$1997-2000$ (Average productivity growth $1.50 \%$ per annum) } \\
\hline FHK & $0.0139(31.0 \%)$ & $0.0147(33.0 \%)$ & $0.0036(8.1 \%)$ & $0.0124(27.8 \%)$ & $-0.0002(-0.4 \%)$ & $0.0126(28.2 \%)$ \\
\hline GR & $0.0157(35.3 \%)$ & $0.0178(40.0 \%)$ & & $0.0110(24.7 \%)$ & $-0.0027(-6.0 \%)$ & $0.0136(30.7 \%)$ \\
\hline
\end{tabular}

Notes: Small and large firms weighted at sector-level; aggregation weighted over 17 two-digit industries by firm's output (TFP) and employment (LP). FHK and GR denote the decomposition methods proposed by Foster et al. (2001), and Griliches and Regev (1995), respectively

Fig. 5 Productivity decomposition, TFP and labour productivity (in percentage) Notes: FHK and GR denote the decomposition methods proposed by Foster et al. (2001), and Griliches and Regev (1995), respectively. Small and large firms weighted at sector-level; aggregation weighted over 17 two-digit industries by firm's output (TFP) and employment (LP)

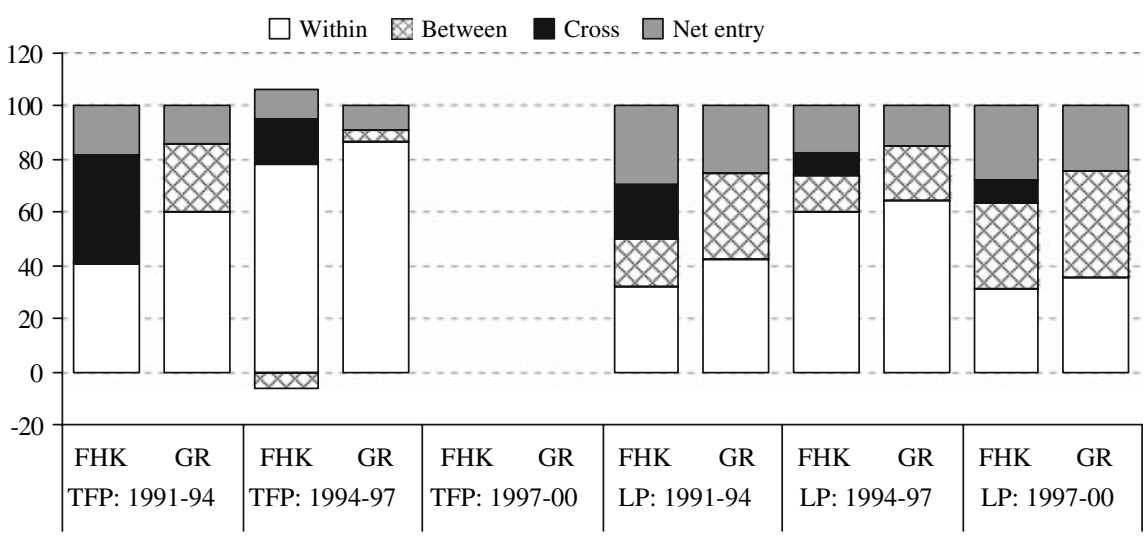

the hypothesis that the cleansing effect is stronger in recessions. The second key finding is that the within effect is stronger when output growth is at its peak, an indication that, under our assumptions, active learning is stronger in expansions. Finally, the across (continuing) firms effectthat is, the sum of the between and cross effects - is clearly lower in the economic upturn, a result that does not seem to totally validate the assumed hypothesis that passive learning should be higher in expansion times. We note, however, that the between effect in the FHK case-that is, the effect given by $\sum_{i \in C} \Delta \theta_{i t}\left(p_{i(t-\tau)}-P_{t-\tau}\right)$ in Eq. 3-is negative in 1994-1997, which is equivalent to say that, on average, the productivity of expanding firms is smaller than that of the overall industry. A possible explanation for this unexpected finding is that the competitive pressure felt by inefficient firms is smaller in good times, especially when barriers to firm mobility are not small as in Portugal (see Boylaud et al. 2000). We cannot exclude the possible perverse effect of cleansing in the first period either, which indeed may have forced an excessive number of firms to exit, impeding potentially superior units to flourish in subsequent periods-the scarring effect mentioned in Sect. 1 above. Our conjecture is therefore that it might be the absence of a sizeable passive learning the factor behind the observed downward trend in productivity growth over the 1990s. 


\section{Concluding remarks}

This paper has analysed the impact of internal and external restructuring on manufacturing productivity growth in the period 1991-2000. An empirical approach was adopted, involving the description of output and employment creation and destruction flows, on the one hand, and the study of productivity growth, on the other.

Using an original unbalanced panel of Portuguese manufacturing firms, we found that resource reallocation, measured by gross job and output flows, shows the usual cyclical pattern: pro-cyclical in the case of creation flows and countercyclical in the case of destruction flows. With respect to productivity, we found that the productivity of entering firms is higher than that of exiting firms. Our decomposition of industry productivity growth also shows that external restructuring has its largest share in economic slowdowns, while internal restructuring makes its largest contribution in economic upturns.

We have provided a detailed view of the process of industrial restructuring in the Portuguese manufacturing sector in the 1990s, a period in which the rate of productivity growth has been clearly decreasing. Aside the fact that 10 years is perhaps too short a period to draw definitive conclusions about the impact of restructuringinternal and external-on productivity growth, especially in relation with the economic cycle, there is clear evidence in favour of the hypothesis that the net entry effect is countercyclical, while the within effect seems to be procyclical, two findings in line with our priors. Under our assumptions, it is surprising though to find that countercyclicality of between and cross effects, a result that we are tempted to allocate to the "scars" of the first sub-period recession and to what seems to be the lack of sufficient firm competition in the Portuguese manufacturing sector, especially in good times.

Acknowledgments We thank two anonymous referees for their most helpful comments on the previous versions of this paper.

\section{References}

Addison JT, Teixeira P (2004) Employment adjustment in two countries with poor reputations: analysis of aggregate, firm, and flow data for Portugal and Germany. Int Econ Econ Policy 1(4):329-348

Aghion P, Saint-Paul G (1998) Uncovering some causal relationships between productivity growth and the structure of economic fluctuations: a tentative survey. Labour Econ 12(2):279-303

Ahn S (2001) Firm dynamics and productivity growth: a review of micro evidence from OECD countries. Economics Department Working Papers no 297. OECD, Paris

Aizcorbe AM (1992) Procyclical labour productivity, increasing returns to labour and labour hoarding in car assembly plant employment. Econ J 102(413):860-873
Albaek K, Sorensen BE (1998) Worker flows and job flows in Danish manufacturing, 1980-91. Econ J 108(451):1750-1771

Audretsch DB, Klepper S (2000) Introduction. In: Audretsch DB, Klepper S (eds) Innovation, evolution of industry and economic growth. Edward Elgar, Cheltenham, pp ix-xxiv

Baily MN, Hulten CR, Campbell D (1992) Productivity dynamics in manufacturing plants. Brookings papers on economic activity microeconomics, pp 187-249

Baldwin JR, Gu W (2002). Plant turnover and productivity growth in Canadian manufacturing. STI Working Papers no. 2. OECD, Paris

Baldwin JR, Dunne T, Haltiwanger J (1998) A comparison of job creation and job destruction in Canada and the United States. Rev Econ Stat 80(3):347-356

Balk BM, Hoogenboom-Spijker E (2003) The measurement and decomposition of productivity change: Exercises on the Netherlands' manufacturing industry. Discussion Paper no. 3001. Statistics Netherlands, Voorburg

Barlevy G (2002) The sullying effect of recessions. Rev Econ Stud 69(1):65-96

Barlevy G (2003) Credit market frictions and the allocation of resources over the business cycle. J Monet Econ 50(8):1795-1818

Barlevy G (2004) The cost of business cycles under endogenous growth. Am Econ Rev 94(4):964-990

Blanchard O (2007) Adjustment within the euro: the difficult case of Portugal. Portuguese Econ J 6(1):1-21

Blanchard O, Portugal P (2001) What hides behind an unemployment rate: comparing Portuguese and US labor markets. Am Econ Rev 91(1):187-207

Boylaud O, Nicoletti G, Scarpetta S (2000) Summary indicators of product market regulation with an extension to employment protection legislation. Economics Department Working Papers no. 226. OECD, Paris

Broersma L, Gautier P (1997) Job creation and job destruction by small firms: an empirical investigation for the Dutch manufacturing sector. Small Bus Econ 9(3):211-224

Caballero RJ, Hammour ML (1994) The cleansing effect of recessions. Am Econ Rev 84(5):1350-1368

Caballero RJ, Hammour ML (1996) On the timing and efficiency of creative destruction. Q J Econ 111(3):805-852

Caballero RJ, Hammour ML (2005) The cost of recessions revisited: a reverse-liquidationist view. Rev Econ Stud 72(2):313-341

Caves R (1998). Industrial organization and new findings on the turnover and mobility of firms. J Econ Lit 36:1947-1982

Davis SJ, Haltiwanger JC (1992) Gross job creation, gross job destruction, and employment reallocation. Q J Econ 107(3):819863

Davis SJ, Haltiwanger JC, Schuh S (1996) Job creation and destruction. MIT Press, Cambridge

DeLong JB (1990) Liquidation cycles: Old-fashioned real business cycle theory and the great depression. NBER Working Paper no. 3546. National Bureau of Economic Research, Cambridge

Disney R, Haskel J, Heden Y (2003) Restructuring and productivity growth in UK manufacturing. Econ J 113(489):666-694

Ericson R, Pakes A (1995) Markov-perfect industry dynamics: a framework for empirical work. Rev Econ Stud 62(1):53-82

Faria A, Fenn P, Bruce A (2002) Determinants of adoption of flexible production technologies: Evidence from Portuguese manufacturing industry. Econ Innov New Technol 11(6):569-580

Faria A, Fenn P, Bruce A (2005) Production technologies and technical efficiency: evidence from Portuguese manufacturing industry. Appl Econ 37(9):1037-1046

Foster L, Haltiwanger J, Krizan CJ (2001) Aggregate productivity growth: lessons from microeconomic evidence. In: Hulten CR, Dean ER, Harper MJ (eds) New developments in productivity analysis. University of Chicago Press, Chicago, pp 303-363 
Garibaldi P (1998) Job flow dynamics and firing restrictions. Eur Econ Rev 42(2):245-275

Geroski PA (1995) What do we know about entry? Int J Indust Organ 13(4):421-440

Griliches Z, Regev H (1995) Firm productivity in Israeli industry: 1979-1988. J Econom 65(1):175-203

Haltiwanger J (1997) Measuring and analyzing aggregate fluctuations: the importance of building from microeconomic evidence. Fed Reserve Bank St. Louis Rev 79(3):55-77

Hart RA, Malley JR (1999) Procyclical labour productivity: a closer look at a stylized fact. Economica 66(264):533-550

Jovanovic B (1982) Selection and the evolution of industry. Econometrica 50(3):649-670

Klette TJ, Mathiassen A (1996) Job creation, job destruction and plant turnover in Norwegian manufacturing. Ann Econ Stat 0(4142):97-125

Monteiro-Barata J (2005) Innovation in the Portuguese manufacturing industry: analysis of a longitudinal company panel. Int Adv Econ Res 11(3):301-314

Mortensen D, Pissarides C (1994) Job creation and job destruction in the theory of unemployment. Rev Econ Stud 61(3):397-415

OECD (2001a) Productivity and firm dynamics: evidence from microdata. Econ Outlook 69:209-223
OECD (2001b) Economic surveys: Portugal 2000/2001. OECD, Paris OECD (2004) Economic surveys: Portugal 2004. OECD, Paris

OECD (2006) National accounts of OECD countries-volume I, main aggregates, 1993-2004. OECD, Paris

Ouyang M (2005). The scarring effect of recessions. Working-Paper no. 050609. University of California-Irvine, Department of Economics, Irvine

Simões VC (1995) Innovation in Portuguese manufacturing industry. In: Molero J (eds) Technological innovation, multinational corporations and new international competitiveness: the case of intermediate countries. Harwood Academic, Langhorne, pp 215-236

Schumpeter JA (1934) Depressions. In: Brown D et al (eds) Economics of the recovery program. Whittlesey House, New York, pp 3-12

Schumpeter JA (1982 [1939]). Business cycles: a theoretical, historical, and statistical analysis of the capitalist process. Porcupine Press, Philadelphia

Teixeira AAC, Fortuna N (2004) Human capital, innovation capability and economic growth in Portugal, 1960-2001. Portuguese Econ J 3(3):205-225

Vainiomaki J, Laaksonen S (1999) Technology, job creation and job destruction in Finnish manufacturing. Appl Econ Lett 6(2):8188 